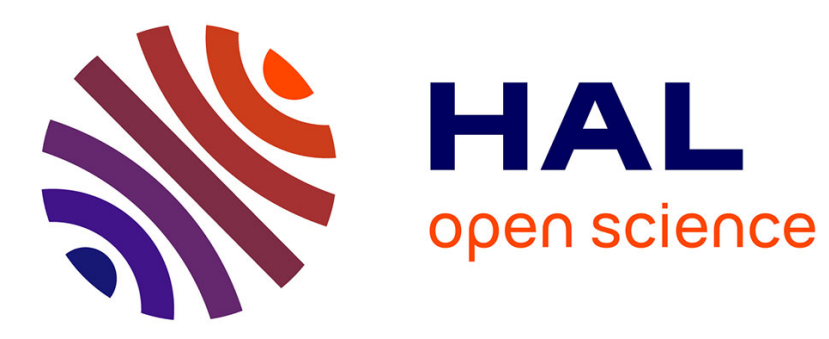

\title{
Copper disodium tetrahydroxide
}

\author{
A. Riou, Yannick Cudennec, Y. Gerault
}

\section{To cite this version:}

A. Riou, Yannick Cudennec, Y. Gerault. Copper disodium tetrahydroxide. Acta Crystallographica Section C: Crystal Structure Communications [1968-2013], 1989, 45, pp.374 - 376. 10.1107/s0108270188012508 . hal-03190067

\section{HAL Id: hal-03190067 https://hal.science/hal-03190067}

Submitted on 6 Apr 2021

HAL is a multi-disciplinary open access archive for the deposit and dissemination of scientific research documents, whether they are published or not. The documents may come from teaching and research institutions in France or abroad, or from public or private research centers.
L'archive ouverte pluridisciplinaire HAL, est destinée au dépôt et à la diffusion de documents scientifiques de niveau recherche, publiés ou non, émanant des établissements d'enseignement et de recherche français ou étrangers, des laboratoires publics ou privés. 
Acta Cryst. (1989), C45, 374-376

https://doi.org/10.1107/S0108270188012508

\title{
Copper Disodium Tetrahydroxide
}

\author{
By A. Riou, Y. Cudennec and Y. Gérault \\ Laboratoire de Chimie des Matériaux Inorganiques et de Cristallographie,20 avenue des Buttes de Coësmes \\ 35043 Rennes CEDEX, France
}

(Received 18 July 1988, accepted 14 October 1988)

\begin{abstract}
CuNa}_{2}(\mathrm{OH})_{4}, \mathrm{Mr}=177.55$, orthorhombique, Pna2 ${ }_{1}, a=6.750(3), b=6.726(5), c=$ 8.993(5) $\AA, V=408.3(7), Z=4, \mathrm{Dx}=2.888 \mathrm{Mg} \cdot \mathrm{m}^{-3}$, Mo $K \alpha, \lambda=0.71069 \AA, \mu=5.442 \mathrm{~mm}^{-1}$, $F(000)=348$, room temperature, $R=0.030$ for 549 reflections. The structure contains $\left[\mathrm{NaO}_{6}\right]$ octahedra and $\left[\mathrm{CuO}_{4}\right]$ square plane. It can be described as deriving from the $\mathrm{NaCl}$ type. 3/4 of the octahedral sites formed by $\mathrm{O}$ atoms are occupied by $\mathrm{Na}$ or $\mathrm{Cu}$ atoms, $1 / 4$ by $\mathrm{H}$ atoms. A study of the hydrogen bonds shows that they are very weak.
\end{abstract}

Introduction. In 1933, Scholder described several new compounds belonging to the ternary system $\mathrm{Na}_{2} \mathrm{O}, \mathrm{MO}, \mathrm{H}_{2} \mathrm{O}$ (M: divalent metal). Since then, several papers have been published; the synthesis was published in 1966 ( Scholder and Schwochow, 1966). In all the previous studies, the syntheses gave rise to powders and no crystallographic study has never been mentioned. The chemical formula of these compounds, mostly $\mathrm{Na}_{2} \mathrm{M}(\mathrm{OH})_{4}$, was deduced only from chemical analysis. These compounds, which are unstable in air, have never been obtained for other alkali metals.

In a recent paper ( Cudennec, Lecerf, Riou and Gerault, 1988), we proposed a new method of synthesis for one compound belonging to these systems: $\mathrm{Na}_{2} \mathrm{Cu}(\mathrm{OH})_{4}$. This method made possible the growth of crystals; therefore a complete crystallographic study became possible. This paper reports the results of the structure determination and discusses peculiar properties.

Experimental. As stated in our previous publication, crystals of $\mathrm{Na}_{2} \mathrm{Cu}(\mathrm{OH})_{4}$ were prepared from a system containing $1 \mathrm{~mol}$ of $\mathrm{CuO}, 10 \mathrm{~mol}$ of $\mathrm{NaOH}$ and $40 \mathrm{~mol}$ of $\mathrm{H}_{2} \mathrm{O}$. The mixture was placed in a dry box using $\mathrm{KOH}$ at room temperature for several weeks to be slowly dehydrated and protected from $\mathrm{CO}_{2}$. Well formed blue octahedral-shaped crystals appeared, of average size about $0.1 \mathrm{~mm}$. Crystals could not be isolated and washed because of their instability; therefore, for all the crystallographic studies, small single crystals were quickly sealed inside a $0.3 \mathrm{~mm}$ Lindemann-glass capillary. A suitable crystal $(0.1 \times 0.1 \times 0.1 \mathrm{~mm})$ was mounted on an Enraf-Nonius CAD-4 diffractometer. Unit-cell constants were determined from a preliminary study by the photographic method and then refined on the basis of 25 carefully centred reflections in the angular range $2<2 \theta$ $<32^{\circ}$. Data were collected in the $\omega-2 \theta$ scan mode, with $\omega$ scan width $(2.00+0.45 \tan \theta)^{\circ}$ and scan amplitude $(1.00+0.35 \tan \theta) \mathrm{mm} ; \theta_{\max }=25^{\circ} .1603$ reflections were measured which were merged to a unique set of $860, R_{\text {int }}=0.031$, of these, 549 were regarded as observed reflections according to I $>\sigma(\mathrm{I})$. Data were corrected for Lorentz and polarization effects, no absorption correction was applied. A periodic check of 3 standard reflections showed no significant intensity variation. The 
$h k l$ range was $0 \leq h \leq 10 ; 0 \leq k \leq 10 ; 0 \leq l \leq 13$. The structure was solved by direct methods and the positions of one $\mathrm{Cu}$, one $\mathrm{Na}$ and three $\mathrm{O}$ atoms belonging to the asymmetric unit were deduced from one of the most probable $E$ maps. The structure was completed from successive Fourier and difference Fourier maps. Full-matrix least-squares refinement was based on $F$ and the function minimized was $\Sigma w\left(\left|F_{0}\right|-\mid F_{c}\right)^{2}$, where $w(F)=1 / \sigma^{2}(F)$. For the seven non-H atoms, which were assigned anisotropic thermal parameters, the refinement converged to $R=0.050$ and $w R=0.056$ for all observed data. At this stage a difference Fourier map revealed the positions of the four $\mathrm{H}$ atoms. Further refinement including the $\mathrm{H}$ atoms led to a final $R$ value of 0.030 and $w R=0.031$. The $\mathrm{H}$ atoms were refined isotropically. The weighting scheme was a non-Poisson contribution with $p=$ 0.050. Corrections were made for anomalous-dispersion and secondary-extinction effects, $\mathrm{g}=1.86 \mathrm{x}$ $10^{-7}$. During the last refinement cycle, the r.m.s. shift/e.s.d. was 0.05 . The final difference Fourier map showed no features higher than $0.8 \mathrm{e} \AA^{-3}$. All crystal structure analyses and refinements were carried out on a PDP 11/60, using the SDP package (Frenz, 1978). Scattering factors were from Cromer \& Waber (1965)*.

Discussion. Coordination polyhedra. Final atomic coordinates and equivalent isotropic temperature factors are given in Table 1. Fig. 1 shows a view of the unit cell of $\mathrm{Na}_{2} \mathrm{Cu}(\mathrm{OH})_{4}$. Bond lengths and angles are given in Table 2 . The structure contains one crystallographic $\mathrm{Cu}$ site and two distinct $\mathrm{Na}$ sites. The coordination of the $\mathrm{Cu}$ atom in the structure is fourfold square planar.

$\mathrm{Cu}$ is coordinated by four $\mathrm{O}$ atoms belonging to $\mathrm{OH}$ groups. The average distance is $1.964 \AA$ with values in the range 1.929-2.021 $\AA$. Two $\mathrm{O}$ atoms, more distant from $\mathrm{Cu}$, complete a very distorted octahedron. Nevertheless, these two $\mathrm{O}$ atoms, whose distances from $\mathrm{Cu}$ are 2.749 and $2.883 \AA$, are very weakly linked. $\mathrm{Na}(1)$ and $\mathrm{Na}(2)$ atoms are each coordinated by six atoms in the form of distorted octahedra. $\mathrm{Na}(\mathrm{l})$ displays $\mathrm{Na}-\mathrm{O}$ distances in the range 2.286-2.569 $\AA$ with a mean value of $2.403 \AA$. $\mathrm{Na}(2)$ shows a less-distorted. octahedron than $\mathrm{Na}(1)$. The average $\mathrm{Na}(2)-\mathrm{O}$ distance is $2.461 \AA$ with values in the range 2.404-2.537 $\AA$.

Hydrogen bonding. The geometrical features of expected $\mathrm{H}$ bonds are given in Table 2. Distances and angles involving the $\mathrm{H}$ atoms are satisfactory. $\mathrm{H}(\mathrm{O} 1)$, which is attached to $\mathrm{O}(\mathrm{l})$, forms an $\mathrm{H}$ bond with $\mathrm{O}(2)$ which is $2.05 \AA$ distant from it. This $\mathrm{H}$ bond, which deviates significantly from linearity $\left[\mathrm{O}(1)-\mathrm{H}(\mathrm{O} 1)---\mathrm{O}(2)=160^{\circ}\right]$, must be considered as relatively weak. Nevertheless, this is the strongest one in the structure. $\mathrm{H}(\mathrm{O} 2)$ forms a very weak $\mathrm{H}$ bond with $\mathrm{O}(\mathrm{l})$ which is $2.18 \AA$ distant from it. As shown in Table 2, $\mathrm{H}(\mathrm{O} 3)$ and $\mathrm{H}(\mathrm{O} 4]$ are too far from their nearest neighbours $\mathrm{O}(\mathrm{l})$ and $\mathrm{O}(2)$ to allow H-bond formation. The present results are in good agreement with the $1 \mathrm{R}$ study. The IR spectrum displays effectively four absorption bands corresponding to the four distinct hydroxyl groups. Of these, two are slightly shifted to the low frequencies $\left(3525\right.$ and $\left.3490 \mathrm{~cm}^{-1}\right)$ whereas the two other bands are not significantly shifted $\left(3600\right.$ and $\left.3570 \mathrm{~cm}^{-1}\right)$.

Crystal packing. As suggested in Fig.1, the four distinct $\mathrm{O}$ atoms present in the $\mathrm{Na}_{2} \mathrm{Cu}(\mathrm{OH})_{4}$, structure are also sixfold coordinated in the form of very distorted octahedra. These octahedra are built of $\mathrm{Na}, \mathrm{Cu}$ and $\mathrm{H}$ cations. $\mathrm{O}(\mathrm{l})$ and $\mathrm{O}(2)$ environments are similar; their nearest neighbours are one $\mathrm{Cu}$, three $\mathrm{Na}$ and two $\mathrm{H}$ atoms. One of the $\mathrm{H}$ atoms surrounding $\mathrm{O}(\mathrm{l})$ or $\mathrm{O}(2)$ corresponds to an $\mathrm{H}$ bond where the atoms $\mathrm{O}(\mathrm{l})$ and $\mathrm{O}(2)$ are acceptors. The distorted octahedra surrounding $\mathrm{O}(3)$ and $\mathrm{O}(4)$ involve two $\mathrm{Cu}$, three $\mathrm{Na}$ and one $\mathrm{H}$ atoms. In this case, one of the two $\mathrm{Cu}$ atoms is very weakly linked to the corresponding $\mathrm{O}(3)$ or $\mathrm{O}(4)$ atom. The similarity betwcen $\mathrm{Na}, \mathrm{Cu}$ and $\mathrm{O}$ octahedral environments suggests that $\mathrm{Na}_{2} \mathrm{Cu}(\mathrm{OH})_{4}$ is derived from the NaCl-type structure.

The structure is built of atomic rows parallel to $|110|,|1-10|$ and $|001|$ axes. These rows form networks respectively parallel ro (100), (1-10) and (001) planes. They are constituted of cations alternating with $\mathrm{O}$ atoms. There are three types of rows forming the networks parallel to (110) or (110) planes. In this case, the atoms appear in the following order:

$$
\begin{aligned}
& \text {...Cu...O...Cu...O... } \\
& \text {..Na...O... } \square \ldots . . . \\
& \text {...Na...O...Na... ... }
\end{aligned}
$$


On the other hand, the networks parallel to (001) involve two types of rows corresponding to:

$$
\begin{aligned}
& \text {...Cu...O...Na...O... } \\
& \text {...Na...O ... } \square . . . O \ldots
\end{aligned}
$$

The symbol $\square$ represents an octahedral site occupied by four $\mathrm{H}$ atoms.

Each atom occupies an octahedral site as in the $\mathrm{NaCl}$ structure, but an important difference is the presence here of an "octahedral hole" occupied by four $\mathrm{H}$ atoms. All the $\mathrm{H}$ atoms are thus confined inside an octahedral hole. So if we consider the four octahedral sites reserved for the cations, three are occupied by $\mathrm{Cu}$ or $\mathrm{Na}$ atoms and the fourth by the $\mathrm{H}$ atoms. If we now compare the structure of $\mathrm{Na}_{2} \mathrm{Cu}(\mathrm{OH})_{4}$ with that of $\mathrm{NaOH}$, it appears that the new compound is more nearly the $\mathrm{NaCl}$ type. The structure of $\mathrm{NaOH}$, stable at room temperature, is built up of slices of the $\mathrm{NaCl}$ structure in which $\mathrm{Na}$ has five nearest neighbourgs at five of the vertices of an octahedron, whereas $\mathrm{Na}_{2} \mathrm{Cu}(\mathrm{OH})_{4}$ contains sixfold-coordinated $\mathrm{Na}$ atoms. Another difference between these structures is that $\mathrm{Na}-\mathrm{O}-\mathrm{H}$ bonds are collinear in $\mathrm{NaOH}$ while the mean angle for $\mathrm{Na}-\mathrm{O}-\mathrm{H}$ bonds in $\mathrm{Na}_{2} \mathrm{Cu}(\mathrm{OH})_{4}$, is $144^{\circ}$.

Structural instability. One of the principal features of the compound studied is its poor stability. There are probably several explanations for this but the presence of four $\mathrm{H}$ atoms confined to a narrow octahedral site is undoubtedly the main reason. Moreover, it is probable that the ionic radius, and consequently the nature of the alkali atom, determines the size of the "octahedral hole", available to the $\mathrm{H}$ atoms. This could be the reason why alkali hydroxymetallates $\mathrm{M}_{2}{ }^{\mathrm{I}} \mathrm{M}^{\mathrm{II}}(\mathrm{OH})_{4}$ have been obtained only for sodium.

- Lists of structure factors and anisotropic thermal paramcters have been deposited with the British Library Document Supply Centre as Supplementary Publication No. SUP $\$ 1496$ (6 pp.). Copies may be obtained through The Executive Secretary, International Union of Crystallography, 5 Abbey Square, Chester CHI $2 H U$, England.

\section{References}

Cromer, D. T. \& WABer, J. T. (1965). Acta Cryst. 18, 104-109.

Cudinni:C, Y., Lecerf, A., Riou, A. \& Gerault, Y. (1988). Eur. J. Solid State Inorg. Chem. In the press.

FRENZ. B. A. (1978). The Enraf-Nonius CAD-4 SDP Real-Time System for Concurrent $X$-ray Data Collection and Crystal Structure Solution. In Computing in Crystallography. cdited by H. Schenk, R. OLTHOF-HAzeKAMp, H. VAN Konincisvet.d \& G. C. BAssi, pp. 64-71. Dein Unï. Press.

Sciotinn, R. \& Scilwochow. F. (1966). Angew. Chem. Int. Ed. Engl. S(12), 1047. 
Table 1. Final atomic coordinates and equivalent isolropic temperature factors for $\mathrm{Na}_{2} \mathrm{Cu}(\mathrm{OH})_{4}$

\begin{tabular}{|c|c|c|c|c|}
\hline \multirow[b]{3}{*}{$\mathrm{Cu}$} & \multicolumn{3}{|c|}{$B_{\mathrm{ec}}=1 L_{1} \Sigma_{j} \beta_{1,} n_{1} \cdot n_{1}$} & \multirow[b]{2}{*}{$B_{r+1}\left(\Lambda^{2}\right)$} \\
\hline & $x$ & $y^{\prime}$ & $z$ & \\
\hline & $0.26417(5)$ & $0 .(00723(6)$ & 0.000 & $0.793(6)$ \\
\hline $\mathrm{Na}(1)$ & $0.5007(3)$ & $0.7148(3)$ & $0.7539(3)$ & $1.26(3)$ \\
\hline $\operatorname{Na}(2)$ & $0.2558(2)$ & $0.0060(2)$ & $0.4950(4)$ & $1.25(2)$ \\
\hline$O(1)$ & $0.2623(4)$ & $0.0113(4)$ & $0.7753(4)$ & $1.37(6)$ \\
\hline$O(2)$ & $0.2827(5)$ & $0.9925(4)$ & $0.2137(4)$ & $1.43(6)$ \\
\hline$O(3)$ & $0.05 .38(4)$ & $0.8078(4)$ & $0.0044(4)$ & $1.08(4)$ \\
\hline$O(4)$ & $0.4643(4)$ & $0.2164(4)$ & $0.0059(3)$ & $1.05(4)$ \\
\hline$\|(() \|)$ & $0.58(1)$ & $0.96(1)$ & $(0.21()(9)$ & $4.0 \cdots$ \\
\hline $11(() 2)$ & (). $25 ; 1)$ & $0.33(1)$ & 0.79 (1) & 1.0 \\
\hline$[1(0) 3)$ & $0.499(4)$ & 0.24 (i) & $0.60(1)$ & $4.0^{\circ}$ \\
\hline$H(04)$ & $0.50(1)$ & $0.25(1)$ & $0.91(1)$ & $4.0^{\star}$ \\
\hline
\end{tabular}

Table 2. Selected bond distances $(\Lambda)$ for $\mathrm{Na}_{2} \mathrm{Cu}(\mathrm{OH})_{4}$ and hydrogen-bonding geometry

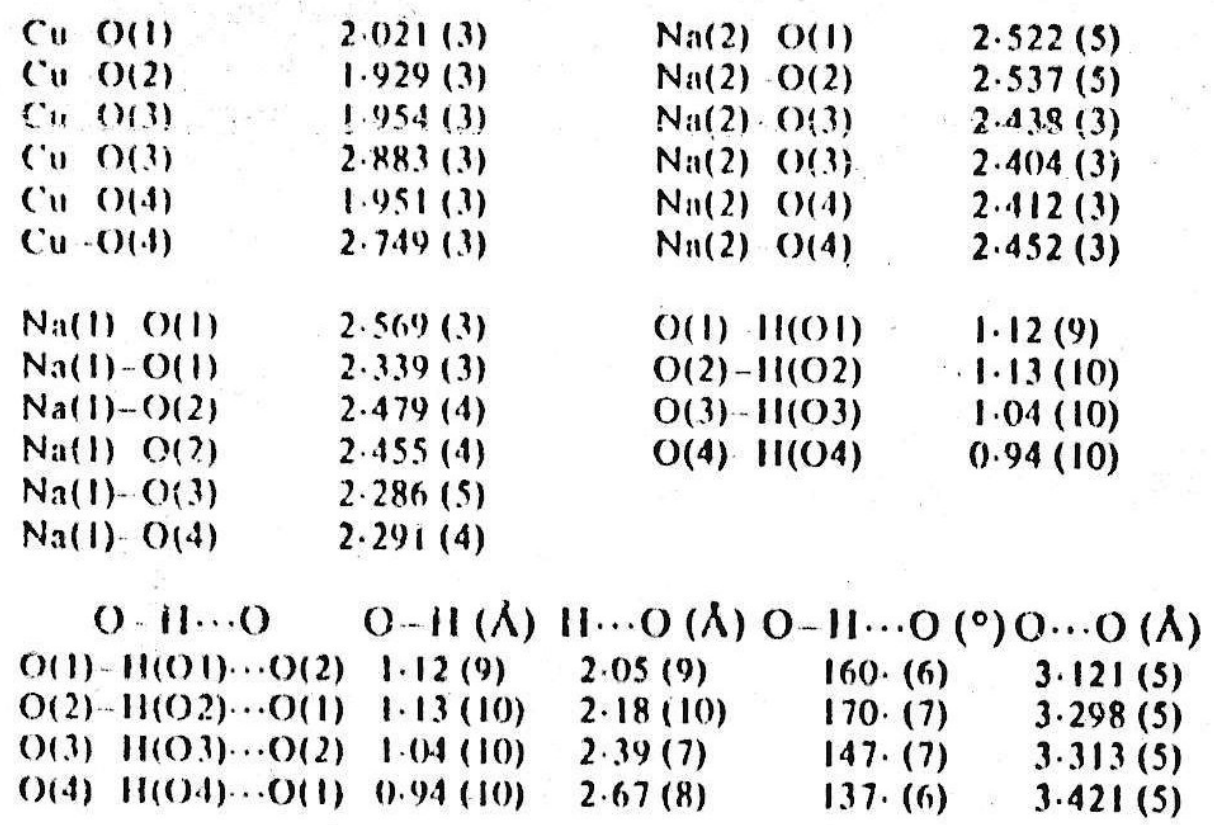




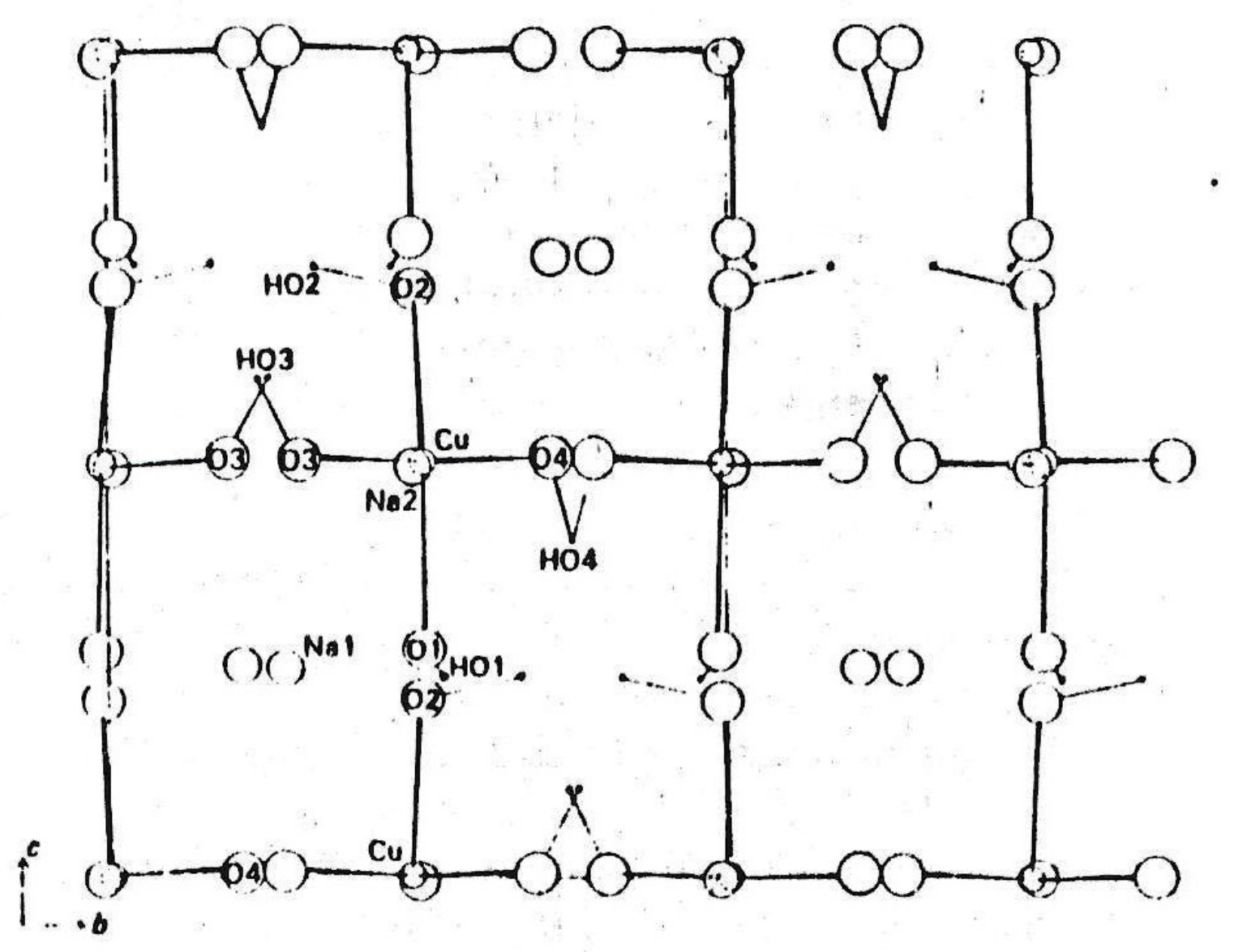

Fig. 1. The unit cell of $\mathrm{CuNa}_{2}(\mathrm{OH})_{4}$. 